\title{
KONSERVASI SUMBER DAYA AIR DAN LINGKUNGAN MELALUHI KEARIFAN LOKAL DI DESA MARGODADI KECAMATAN SEYEGAN KABUPATEN SLEMAN YOGYAKARTA
}

\author{
Rita Dewwi Triastianti, Nasirudin, Sukirno, dan Warsiyah \\ Institut Teknologi Yogyakarta \\ Email: ritastt1@yahoo.com
}

\begin{abstract}
Local wisdom has been derived from the expression of ancestors that grows and develops especially in rural life norms which could be related to local food security. The question will be on what kind of natural resources can be managed without damaging the environment. In line with the issue, we need to know the local natural resources and manage it through the people behavior by following the local norms. Margodadi Village located in the western part of Sleman regency. The condition of society and its natural resources and environment is still original and unique. Activities undertaken by the community are mostly simple and traditional. Live harmony between individuals in society still exists. Natural resources and the environment are utilized by the community from generation to generation to this day, such as the existence of clean water - lake which is considered out of a big banyan tree. This water comes out of the ground under the tree and is called "Tuk Sibedug". The water of this lake is often used for bathe rituals in a pond and the rest flows into the river for farming irrigation especially rice fields. By knowing the inner or spiritual strength of each individual, the norms of life will grow and develop, so that natural resources and environment can be managed better. Natural resources from the agricultural, livestock, fishery and small industries sectors are possible to potentially generate per capita income of $519 \mathrm{~kg}$ per person per year. This shows the existence of local food security in the villages of Seyegan that has been achieved.
\end{abstract}

Keywords: Conservation; Local Wisdom; Tap Water.

\begin{abstract}
ABSTRAK
Kearifan lokal yang berasal dari ungkapan-ungkapan nenek moyang yang tumbuh dan berkembang di Pedesaan dalam bentuk norma-norma kehidupan, mungkinkah terkait dengan ketahanan pangan lokal. Cara yang seperti apakah sumber daya alam dapat dikelola tanpa merusak lingkungan. Untuk itu perlu diketahui sumber daya alam lokal dan lingkungannya yang dikelola melalui perilaku masyarakat yang mengikuti norma-norma yang tumbuh dan berkembang didalamnya. Desa Margodadi yang terletak di bagian Barat Kabupaten Sleman, kondisi masyarakat dan Sumber Daya Alam serta Lingkungan masih sangat asli dan spesifik. Kegiatan-kegiatan yang dilakukan oleh masyarakat masih banyak yang bersifat sederhana (tradisional). Kerukunan antar individu dalam masyarakat masih eksis. Sumber Daya Alam dan Lingkungan masih banyak yang asli, yang dimanfaatkan oleh masyarakat secara turuntemurun hingga sekarang, seperti adanya telaga yang airnya sangat bening yang dianggap keluar dari pohon beringin yang besar. Air ini keluar dari pohon tersebut dan dinamakan "Tuk Sibedug". Air telaga ini sering untuk mandi ritual dan sisa airnya mengalir ke sungai untuk irigasi persawahan. Dengan mengetahui kekuatan batin atau spiritual setiap individu, maka norma-norma kehidupan akan tumbuh dan berkembang, sehingga sumber daya alam dan lingkungan dapat dikelola dengan baik dan benar. Sumber daya alam dari sektor pertanian, peternakan, perikanan dan industri kecil, ternyata mampu menghasilkan pendapatan perkapita sebesar $519 \mathrm{~kg}$ per orang per tahun. Hal ini menunjukkan
\end{abstract}


adanya ketahanan pangan lokal di Desa-desa se Kecamatan Seyegan sudah tercapai.

Kata Kunci: Air Tuk; Kearifan Lokal; dan Konservasi.

\section{PENGANTAR}

Air merupakan unsur penting dalam kehidupan.Hampir seluruh kehidupan di dunia ini tidak terlepas dari adanya unsur air. Sumber utama air yang mendukung kehidupan di bumi ini adalah laut, dan semua air akhirnya akan kembali ke laut yang bertindak sebagai "Reservoir" atau penampung. Air dapat mengalami daur hidrologi. Selama menjalani daur itu air selalu menyerap zat-zat yang menyebabkan air itu tidak lagi murni. Oleh karena itu, pada hakikatnya tidak ada air yang betul-betul murni (Sukirno, 2014).

Desa Margodadi setiap tahun hingga sekarang selalu diadakan upacara kirab dari Balai Desa Margodadi menuju ke Tuk Sibedug. Upacara adat ini digelar untuk mengenang perjalanan Sunan Kalijaga ketika menyebarkan ajaran agama Islam di Desa Margodadi. Tuk Sibedug menjadi sebuah legenda karena konon ketika Sunan Kalijaga menyebarkan agama Islam di wilayah ini bersama pengikutnya beristirahat di Dusun Mranggen Desa Margodadi. Sunan Kalijaga bersama pengikutnya saat melakukan shalat Luhur kesulitan mendapatkan air wudhu. Sunan lantas menancapkan tongkatnya ke tanah, ketika dicabut keluarlah air (Tuk) karena bertepatan dengan suara bedug (pertanda adanya waktu untuk shalat), maka selanjutnya dinamakan Tuk Sibedug. Air ini dipercaya mempunyai daya magis yang dapat melancarkan tercapainya cita-cita (Yubaidi, 2013). Air ini tertampung ke dalam bentuk sendang, dan sendang ini oleh masyarakat dipugar dengan ukuran 5 meter kali 6 meter. Air ini hingga sampai sekarang selalu mengalir terus atau "ngetuk" dengan debit sekitar 1,5 m³ menit dan berwarna sangat bening sepanjang tahun. Air Tuk Sibedug yang bening ini tidak dipengaruhi oleh air sungai Selokan Mataram yang keruh yang jaraknya sekitar 10 meter. Di pinggir Sendang ini tumbuh pohon beringin yang cukup besar. Di samping itu, didirikan juga tempat shalat berbentuk langgar dan rumah untuk Si Juru Kunci. Sampai sekarang air tersebut digunakan untuk mandi dan mencuci oleh masyarakat sekitar. Air yang dari sendang ini keluar menuju ke sungai dan dapat digunakan sebagai irigasi persawahan.

Jumlah penduduk 8.163 jiwa yang lakilaki 4.010 jiwa dan perempuan 4.253 jiwa. Jumlah KK (Kepala Keluarga) sebanyak 1.026 yang beragama Islam 7.690 jiwa, Katholik 339 jiwa, Kristen 79 jiwa dan Hindu 56 jiwa. Organisasi Islam terbesar adalah NU diikuti Muhammadiyah.

Mata pencaharian dari Sumber Daya Alam adalah bertani (padi, palawija, tembakau), beternak (kerbau, sapi, kambing, ayam, bebek, dan angsa) perikanan/kolam, kerajinan (gerabah, keset, wayang kulit, anyaman bambu), pertambangan/galian $\mathrm{C}$ (genteng, batu bata). Mata pencaharian di sektor jasa adalah PNS (guru 298 jiwa, ABRI/ sipil 318 jiwa), perkreditan rakyat 6 jiwa, angkatan darat 12 jiwa dan bekerja di pasar, warung, toko, kios, angkringan, serta di bidang pariwisata. Sektor pariwisata yang ada adalah wisata pegunungan, wisata budaya dan religi (upacara adat, pemidangan, dan ziarah). Dari jumlah penduduk 8.163 jiwa ini yang bekerja di bidang jasa hanya sekitar $14 \%$ dan yang $86 \%$ nya di bidang produksi barang yang memanfaatkan sumber daya alam (tanah pertanian, galian $\mathrm{C}$ dan hutan masyarakat). Untuk itu pertanyaannya, konservasi sumber daya alam berbasis kearifan lokal yang bagaimana ada di Desa Margodadi Kecamatan Seyegan serta sejauhmana hubungan antara sumber daya alam dan lingkungan dengan norma-norma juga nilai-nilai (kearifan lokal) yang berlaku hingga saat ini.

Bagi masyarakat Desa Margodadi untuk menjaga ketahanan pangan dan memelihara sumber daya alam dan lingkungan, dengan selalu memperhatikan dan melestarikan kearifan lokalnya sehingga informasi tentang kearifan lokal di daerah tersebut merupakan pengetahuan baru, sehingga memacu untuk mempelajarinya lebih dalam dan luas terutama daerah-daerah lain. 


\section{Sumber Daya Alam}

Sumber daya alam seperti air, udara, lahan, minyak, ikan, hutan, dan lain-lain merupakan sumber daya yang esensial bagi kelangsungan hidup manusia. Pengelolaan sumber daya alam yang baik akan meningkatkan kesejahteraan umat manusia, tetapi bila pengelolaannya tidak baik akan berdampak buruk bagi umat manusia. Oleh karena itu, persoalan mendasar sehubungan dengan pengelolaan sumber daya alam adalah bagaimana mengelola sumber daya alam tersebut agar dapat menghasilkan manfaat yang sebesar-besarnya bagi manusia dengan tidak mengorbankan kelestarian sumber daya alam itu sendiri beserta lingkungannya (Fauzi, 2004). Secara umum sumber daya alam dapat diklasifikasikan ke dalam dua kelompok: Pertama, kelompok stok bahwa Sumber daya ini dianggap memiliki cadangan yang terbatas sehingga eksploitasi terhadap sumber daya tersebut akan menghabiskan cadangan sumber daya. Apa yang dimanfaatkan sekarang mungkin tidak lagi tersedia di masa mendatang. Dengan demikian, sumber daya stok dikatakan tidak dapat diperbaharui (non renewable) atau terhabiskan (exhaustible). Termasuk ke dalam kelompok ini antara lain sumber daya mineral, logam, minyak, dan gas bumi.

Kedua, Kelompok kedua adalah sumber daya alam yang disebut "flows" (alur). Pada jenis sumber daya ini jumlah kuantitas fisik dari sumber daya berubah sepanjang waktu. Berapa jumlah yang dimanfaatkan sekarang, bisa mempengaruhi atau bisa juga tidak mempengaruhi ketersediaan sumber daya di masa mendatang. Dengan kata lain, sumber daya jenis ini dikatakan dapat diperbaharui (renewable). Dalam kelompok sumber daya ini, untuk regenerasinya ada yang tergantung pada proses biologi dan ada yang tidak. Ikan dan hutan misalnya, termasuk ke dalam kelompok sumber daya yang regenerasinya tergantung pada proses biologi (reproduksi). Sementara energi surya, gelombang pasang surut, angin, udara dan sebagainya termasuk ke dalam sumber daya alam yang tidak tergantung pada proses biologi.

\section{Kearifan Lokal}

Keseimbangan lingkungan hidup perlu dijaga dengan kesadaran tinggi oleh masyarakat lokal. Hal ini bukan sesuatu yang baru bagi masyarakat lokal karena nenek moyang telah memiliki kearifan dalam memelihara lingkungan hidup. Dengan caranya sendiri sesuai dengan pola pikir dan tradisi yang berlangsung pada zamannya telah mampu menciptakan cara-cara untuk melestarikan keseimbangan lingkungan.

Menurut kamus umum Bahasa Indonesia terbitan Balai Pustaka tahun 1976, kata arif dari kearifan diartikan bijaksana atau kebijaksanaan. Rahail (1995) menyebutkan bahwa masyarakat lokal merupakan istilah masyarakat adat. Masyarakat adat adalah masyarakat yang belum sepenuhnya terjangkau atau tersentuh oleh berbagai kemajuan. Masyarakat lokal ini merupakan masyarakat yang unik dan khas, yang banyak berbeda dengan masyarakat modern. Laksono (1995) menyebutkan kearifan sebagai produk historis masyarakat dalam rangka adaptasi dengan lingkungannya, di dalamnya terdapat bagian-bagian yang mempunyai implikasi transcendental (ajeg atau sulit dipahamkan sekalipun pengalaman manusia biasa) karena menyangkut soal hidup mati yang tidak pernah terselesaikan. Akan tetapi, ada bagian-bagian yang justru harus berubah-ubah dan aktual sesuai dengan perkembangan situasi dan kondisi. Lebih lanjut Nababan (1995) mengatakan bahwa kebudayaan tradisional, khususnya dalam hal pengelolaan sumber daya alam telah memiliki prinsip-prinsip konservasi, yaitu (1) Rasa hormat yang mendorong keselarasan manusia dengan alam sekitarnya. (2) Rasa memiliki suatu kawasan atau sumber daya alam sebagai kepemilikan bersama (communal property), sehingga mengikat semua warga untuk menjaga dan mengamankan sumber daya alam dari gangguan liar. (3) Sistem pengetahuan masyarakat setempat (local knowledge system) yang memberi kemampuan kepada masyarakat untuk memecahkan masalah-masalah yang dihadapi dapat memanfaatkan sumber daya alam yang terbatas. (4) Daya adaptasi dalam penggunaan teknologi sederhana yang tepat 
guna dan hemat sesuai kondisi alam setempat. (5) Sistem alokasi dan penegakan aturan adat yang bisa mengamankan sumber daya milik bersama dari penggunaan berlebihan. (6) Mekanisme pemerataan hasil panen atas sumber daya milik bersama agar dapat mcncegah munculnya kesenjangan yang berlebihan di dalam masyarakat.

Kearifan lokal terbentuk karena adanya hubungan antara masyarakat tradisional dengan ekosistem di sekitarnya. Masyarakat memiliki sistem kepercayaan hukum dan pranata adat, pengetahuan, dan cara mengelola sumber daya alam secara lokal. Sebagai komunitas mereka memiliki ketergantungan dan keyakinan rohani tentang ekosistem setempat (Kusumaatmadja, 1995). Beberapa penelitian menunjukkan bahwa masyarakat lokal di beberapa daerah di Indonesia mampu untuk mengelola lingkungan dan sumber daya alamnya. Kajian tentang etnobotani, kebun kemenyan di Tapanuli Utara, masyarakat Dayak, kebun karet di Jambi, kebun damar di Krui, Lembo di Kalimantan Timur dan hutan adat di Tenganan, ini semua merupakan contoh dalam mengelola hutan secara lestari. Pengetahuan masyarakat lokal terhadap sumber daya alam membentuk kearifan terhadap pengelolaan hutan (Adimihardja, 1994).

Kebudayaan tradisional mengarah kepada terpeliharanya lingkungan dan kelangsungan hidup masyarakatnya. Salah satu contoh kebudayaan tradisional ini adalah pola hidup yang dipraktekkan oleh masyarakat Petalangan di Riau. Petalangan menyebutkan bahwa hutan, tanah beserta isinya bukan hanya sekedar untuk sumber nafkah, tetapi juga menjadi sumber budaya dan nilai yang dianut, serta menjadi jati diri masyarakatnya. Berbagai budaya dan simbol-simbolnya menunjukkan persebatinan mereka dengan alam sekitar, yang mereka kekalkan dengan berbagai ungkapan adat, upacara adat, dan tradisi. Pelanggaran terhadap ketentuan adat yang berkaitan dengan hutan, tanah dan isinya dikenakan sanksi. Acuan seperti ini menyebabkan hutan tanah petalangan selama ratusan tahun terpelihara dengan baik serta memberikan kedamaian bagi masyarakatnya (Effendy, 1994).

Menurut Paul H. Landis, 1948 (dalam Rahatjo, 1999) ciri-ciri kebudayaan masyarakat desa sebagai berikut:

Pertama, sebagai konsekuensi dari ketidakberdayaan masyarakat terhadap alam, maka mereka mengembangkan adaptasi yang kuat terhadap lingkungan alamnya. Seperti misalnya, pertanian sangat tergantung kepada keadaan atau jenis tanah, tingkat kelembaban, ketinggian tanah, topografi, banyaknya curah hujan dan lain-lain. Lingkungan alam yang seperti ini elemennya untuk setiap daerah yang satu dengan lainnya cukup bervariasi. Dominasi alam yang kuat terhadap masyarakat desa akan mengakibatkan tebalnya kepercayaan mereka terhadap takhayul. Ketundukan masyarakat desa terhadap alam akan menyebabkan rendahnya kesadaran yang tinggi akan pentingnya waktu. Hal ini dapat dimengerti, karena alam memiliki irama sendiri. Alam tidak menempatkan orang ke dalam kotak-kotak waktu, melainkan orang sendirilah yang menciptakan kotak-kotak waktu. Tanaman memiliki proses alami dengan paket waktu tersendiri, terlepas dari pengaturan dan campur tangan manusia. Kedua, Besarnya pengaruh alam akan berakibat orang desa cenderung bersifat praktis. Mereka tidak begitu mengindahkan segi keindahan dan ornamenornamen lain. Mereka hidup dalam kelompok dan lingkungan primer, saling kenal, dan saling akrab. Pada situasi semacam ini kurang memungkinkan untuk menyembunyikan sesuatu dari teman atau tetangga. Mereka tidak perlu bicara panjang lebar dan berbasa-basi. Hal ini mendorong tumbuh dan berkembangnya sifat-sifat jujur, terus terang, dan suka bersahabat atau friendly.

Ketiga, Pengaruh alam akan tercipta standar moral kaku di kalangan masyarakat desa. Moralitas dipandang sebagai sesuatu yang absolute (final). Tidak ada kompromi antara yang baik dan buruk, cenderung pada pemahaman yang bersifat hitam putih. Dengan kata lain, tidak ada pengertian yang 
bersifat relatif mengenai baik dan buruk. Seperti misalnya penafsiran ayat-ayat suci dalam kitab suci, ditafsirkan secara harfiah saja. Kebudayaan Jawa masih tetap pada dasar hakikinya, yang menurut berbagai kitab Jawa klasik dan peninggalan lainnya dapat dirumuskan secara singkat (Suwardi E, 2005) sebagai berikut: Pertama, Orang Jawa percaya dan berlindung kepada Sang Pencipta, Zat Yang Maha Tinggi, penyebab dari segala kehidupan, adanya dunia dan alam semesta dan hanya ada satu Tuhan, yang awal dan yang akhir.

Kedua, Orang Jawa yakin bahwa manusia adalah bagian dari kodrat alam. Manusia dan kodrat alam senantiasa saling mempengaruhi, tetapi manusia harus sanggup melawan kodrat untuk dapat mewujudkan kehendaknya, citacita atau fantasinya untuk hidup selamat sejahtera dan bahagia lahir dan batin. Hasil perjuangannya (melawan kodrat) berarti kemajuan atau pengetahuan bagi lingkungan atau masyarakatnya, maka terjalinlah kebersamaan hidup rukun, rasa saling menghormati, tenggang rasa (tepa slira), budi luhur, rukun, damai dan mawas diri.

Ketiga, Rukun damai berarti tertib pada lahirnya dan damai pada batinnya, sekaligus membangkitkan sifat luhur dan peri kemanusiaan. Orang Jawa menjunjung tinggi amanat berupa Sa-santi atau semboyan "mamayu hayuning bawono" (memelihara kesejahteraan dunia).

Keragaman adat istiadat dan tradisi didasarkan atas keberagaman sistem mata pencaharian. Bila diruntut jauh ke belakang nenek moyang kita datang dari berbagai daerah asal akan menyumbangkan kekayaan adat dan tradisi (pola kebudayaan). Sejak zaman pra sejarah telah terjadi migrasi dari berbagai bangsa ke Indonesia, seperti migrasi bangsa Cina, Tebet, Birma, Arab, dan lain-lain. Sukusuku bangsa ini dengan hukum adatnya akan sangat berpengaruh terhadap masyarakat desa yang berada dalam wilayahnya. Pengaruh ini dalam bentuk kepercayaan, bahasa atau dialek, kesenian, adat istiadat, dan sebagainya. Lebih lanjut keberagaman dalam pola kebudayaan di antara masyarakat desa-desa di Indonesia juga ditentukan oleh perbedaan faktor yang mengintegrasikan mereka. Integrasi desa-desa tersebut ada yang didasarkan ikatan daerah dan ada yang berdasarkan ikatan darah (geneologis). Di desa-desa di Jawa terkadang untuk menggantikan fungsi sistem kekerabatan dalam mempererat rasa persaudaraan, diciptakan suatu legenda tentang cikal bakal suatu desa atau dusun yang diakui oleh pendidik sebagai nenek moyang mereka bersama, bahkan sering diakui adanya danyang (penjaga desa yang bersifat gaib) yang menjadi pelindung desa itu. Oleh karena itu, desa atau dusun yang demikian itu dapat mempertebal rasa kebersamaan di antara mereka. Kepercayaan seperti ini umumnya menjadi landasan sakral dari tradisi yang ada dan beradaptasi dengan lingkungannya, sehingga dapat menjadi pedoman perilaku anggota masyarakat. Munculnya tradisi semacam ini akibat isolasi fisik karena beratnya kondisi geografis serta rendahnya tingkat teknologi. Akan tetapi, sering terjadi juga perubahan kondisi yang mampu mendobrak isolasi fisik ini, sehingga dapat menyingkirkan kekuatan tradisi tersebut (Soemardjan, 1964).

Konsep kebudayaan (culture) selalu terkait dengan konsep struktur sosial. Struktur dipahami sebagai susunan. Konsep struktur sosial menggambarkan pola hubungan antar individu dalam kelompok. Hal ini dapat dijelaskan dengan konsep-konsep norma, status, peran dan lembaga (organisasi atau asosiasi). Dalam setiap lembaga, maka setiap anggota pasti memiliki status tertentu. Status ini dilekati oleh nilai tertentu yang bersumber pada nilai kebudayaan dan struktur dalam suatu masyarakat terjadi keadaan saling mendukung dan membenarkan. Apabila terjadi perubahan dalam kebudayaan akan diikuti perubahan dalam struktur, demikian juga sebaliknya Mayor Polak, 1966 (dalam Rahardjo, 1999).

Dalam konsep struktur sosial dipilih menjadi dua yaitu struktur sosial vertikal dan horizontal. Struktur sosial vertikal atau stratifikasi sosial atau pelapisan sosial 
yang menggambarkan kelompok-kelompok sosial dalam susunan yang bersifat hirarkis, berjenjang. Dengan demikian ada kelompok masyarakat berkedudukan tinggi (lapisan atas), sedang (lapisan menengah) dan rendah (lapisan bawah). Struktur sosial horizontal atau diferensial sosial lebih tertuju kepada variasi kekayaan yang ada dalam masyarakat. Semakin maju dan berkembang masyarakatnya, maka semakin bervariasi dan kompleks pengelompokannya baik secara kuantitatif maupun kualitatif, Smith dan Zort, 1970 (dalam Rahardjo, 1999).

Di tingkat teoritik sering dipertanyakan, mengapa dalam masyarakat terjadi pelapisanpelapisan. Justru dalam hal ini karena kehidupan manusia dilekati oleh nilai. Manusia selalu memiliki nilai karena mereka penyandang nilai. Keberadaan nilai selalu mengandung kelangkaan (tidak atau bukan kebanyakan orang), tidak mudah didapat sehingga ada harganya (nilainya bagi yang menyandangnya). Siapa yang memperoleh lebih banyak hal yang bernilai, maka akan semakin terpandang dan tinggi kedudukannya. Secara umum hal-hal yang mengandung nilai, selalu berkaitan dengan harta atau kekayaan, jenis mata pencaharian, pengetahuan atau pendidikan, keturunan, keagamaan dan unsurunsur biologisnya (usia dan jenis kelamin). Bagi masyarakat desa (pertanian) yang dipandang bernilai adalah lahan pertaniannya. Dengan demikian seberapa besar pemilikan lahan pertanian akan menentukan seberapa tinggi kedudukannya di tengah masyarakat. Keberadaan pelapisan sosial juga tidak terlepas dari tingkat struktur sosial horizontalnya atau diferensiasi masyarakatnya. Bila tingkat diferensiasinya juga kurang terlihat, maka jarak sosialnya tidak terlalu tajam.

Dalam masyarakat juga dikenalnya struktur biososial. Faktor biologis ini (usia dan jenis kelamin) menunjukkan struktur sosial vertikal dan horizontal. Di samping usia dan jenis kelamin dalam biososial juga ada perkawinan; suku bangsa, dan lain-lain. Kaum laki-laki tergolong lebih kuat dibanding kaum wanita. Dengan demikian kaum lakilaki lebih banyak berperan dan dominan dalam kehidupan kelompok atau masyarakat. Dalam ethnologi (ilmu suku bangsa) terdapat konsep potlatch yaitu semacam prinsip bahwa siapa yang berada di pihak yang memberi akan berkedudukan lebih tinggi dibanding dengan pihak yang menerima. Kaum wanita merupakan cerminan norma sosial seperti "konco wingking" (wanita hanya untuk urusan dapur) dan ada istilah "swargo nunut nroko katut" (suami masuk surga atau neraka, istri hanya berstatus ikutan). Kedudukan yang tinggi kaum tua (usianya) dilegitimasi dengan ketentuan tradisi di lingkup pedesaan. Hal ini terungkap istilah "sesepuh" "pini sepuh", "tetua" dan lain-lain (Damardjati S, 2005).

Masyarakat selalu membutuhkan sesuatu dalam hidup dan kehidupannya. Apabila untuk mencapai kepentingan, maka diperlukan sebuah lembaga atau asosiasi. Asosiasi melayani kepentingan umum bukan hanya pribadi, dan jika dilakukan secara teratur, tetap dan diterima oleh umum, maka asosiasi dapat menjadi lembaga, yang berpusat kepada aktivitas-aktivitas untuk memenuhi kebutuhan dalam kehidupan masyarakat. Bentuk-bentuk kerjasama langsung dalam masyarakat seperti gotong-royong akan terlembagakan dengan kuat di tengah kehidupan masyarakat. Bentuk masyarakat desa yang bersifat kekeluargaan lama-lama berkembang menjadi sebuah perkumpulan, koperasi, arisan trah, arisan RT/ RW, dusun, dan lain-lain (Suwardi E, 2005). Gotong royong untuk kepentingan umum seperti pembuatan jalan, gugur gunung, dan sebagainya.

\section{Metode}

Lokasi bahwa lokasi penelitian diambil di Desa Margodadi Kecamatan Seyegan, Kabupaten Sleman, Propinsi DIY. Objek penelitian ini adalah Kearifan lokal penduduk di Desa Margodadi Kecamatan Seyegan, Kabupaten Sleman, Propinsi DIY. Variabel yang menjadi acuan variabel bebas (Penyebab), yaitu Kearifan Lokal bahwa pelestari,pengkonservasi, penjaga, pemeliharaan atau pengawet yang dilakukan secara arif, bijak, dan tidak merusak. Variabel Terikat (Akibat), yaitu Sumber Daya Alam sebagai seperti tanaman pangan, hewan 
ternak, perikanan, dan pertambangan golongan C (untuk industri kecil) yang terkonservasi oleh lingkungan. Variabel Pendukung, yaitu Lingkungan, seperti pohon-pohon penghasil air ("Tuk" atau sumber-sumber air yang lestari).

\section{Teknik Sampling}

Pengambilan sampel dilakukan dengan metode purpose sampling, yaitu sampel ditentukan lebih dulu yang dapat menggambarkan keterwakilan populasi. Pengambilan data bisa melalui beberapa informan, dengan ketentuan dalam 1 dusun dapat diambil 1 sampai 2 orang, tetapi dalam kondisi tertentu misalkan untuk menambah atau mengurangi data, sehingga dalam 1 desa informan bisa diambil sebanyak 2 sampai 5 orang (SURito). Dengan demikian cara pengambilan data sebagai berikut: Pertama, Untuk mencari data sumber daya alam lokal perlu 4 informan dalam 1 Desa Margodadi yang sumbernya dari para tokoh petani.

Kedua, Untuk mencari data lingkungan yang mengkonservasi sumber daya alam juga perlu 4 informan yang sumbernya dari tokoh masyarakat seperti Ketua RT, Ketua RW, Kadus, dan Kades. Ketiga, Untuk mencari data kearifan lokal di Desa Margodadi diambil setiap dusun 2 informan, yang jumlah dusunnya sebanyak 16 , sehingga jumlah informannya sebanyak 2 kali 16 sama dengan 32 informan, yang diambil dari Budayawan Lokal, Seniman, Tokoh Adat dan Tokoh Agama.

\section{Analisis Data}

Data-data ini bersifat kualitatif yang bersumber dari informan, yang dapat disajikan/disusun dalam bentuk tabel. Datadata yang ditabelkan sebagai berikut: (1) Sumber Daya Alam Lokal, (2) Lingkungan yang mengkonservasi sumber daya alam, (3) Kearifan Lokal yang menjaga dan memelihara sumber daya alam dan lingkungan. Datadata yang ditabelkan tersebut merupakan hasil analisis, yang selanjutnya perlu ada pembahasan yang berisi tentang sebab akibat.

\section{HASIL DAN PEMBAHASAN}

\section{Sumber Daya Alam Lokal}

Kegiatan penghasil pangan dalam penelitian ini berasal dari Sumber Daya Alam Lokal dalam bentuk pertanian, peternakan, perikanan, dan pertambangan golongan C maupun industri kecil. Data-data Sumber Daya Alam Lokal ini dapat diambil dari tokohtokoh petani sebagai informan yang jumlahnya sebanyak delapan orang.Sumber Daya Alam Lokal ini, data-datanya dapat disusun kedalam tabel 1, dan juga menginformasikan jenis dan jumlah Sumber Daya Alam Lokal itu sendiri.

Tabel 1.Data-Data Sumber Daya Alam Lokal Di Kecamatan Seyegan Yang Disampaikan Oleh 4 Informan.

\begin{tabular}{|c|c|c|c|c|c|}
\hline \multirow{2}{*}{ 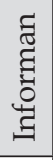 } & \multirow[b]{2}{*}{ Lokasi (Dusun) } & \multicolumn{4}{|c|}{ Sumber Daya Alam Lokal } \\
\hline & & Pertanian & Peternakan & Perikanan & $\begin{array}{c}\text { Pertambangan gol. } \\
\text { C/Industri Kecil }\end{array}$ \\
\hline 1. & $\begin{array}{ll}\text { 1. } & \text { Karang } \\
\text { Beran } \\
\text { 2. Kandangan }\end{array}$ & Padi 90\% KK lebih & $\begin{array}{ll}\text { 1. } & \text { Sapi } 17 \text { ekor } \\
\text { 2. } & \text { Kerbau } 12 \text { ekor } \\
\text { 3. } & \text { Kambing } 65 \text { ekor } \\
\text { 4. } & \text { Ayam setiap KK } \\
\end{array}$ & \begin{tabular}{|ll} 
1. & Lele 32 kolam \\
2. & Gurameh 8 kolam \\
3. Nila dan sejenisnya \\
\\
43 kolam \\
\end{tabular} & 1. Genteng $68 \mathrm{KK}$ \\
\hline 2. & $\begin{array}{ll}\text { 1. } & \text { Kurahan } 3 \\
\text { 2. } & \text { Kurahan } 4\end{array}$ & Padi $90 \%$ KK lebih & $\begin{array}{ll}\text { 1. } & \text { Sapi } 18 \text { ekor } \\
\text { 2. } & \text { Kerbau } 8 \text { ekor } \\
\text { 3. } & \text { Kambing } 84 \text { ekor } \\
\text { 4. } & \text { Ayam setiap KK } \\
\end{array}$ & \begin{tabular}{|ll} 
1. & Lele 44 kolam \\
2. & Gurameh 11 kolam \\
3. Nila dan sejenisnya & \\
& 36 kolam \\
\end{tabular} & $\begin{array}{l}\text { 1. Genteng } 22 \mathrm{KK} \\
\text { 2. Anyam- } \\
\text { anyaman } 6 \mathrm{KK}\end{array}$ \\
\hline 3. & $\begin{array}{ll}\text { 1. Japanan } \\
\text { 2. } \\
\text { Mrangge }\end{array}$ & $\begin{array}{ll}\text { 1. } & \text { Padi 55\% KK } \\
\text { 2. } & \text { Palawija } 45 \% \\
\text { KK }\end{array}$ & $\begin{array}{ll}\text { 1. } & \text { Sapi } 52 \text { ekor } \\
\text { 2. } & \text { Kerbau } 12 \text { ekor } \\
\text { 3. } & \text { Kambing } 36 \text { ekor } \\
\text { 4. } & \text { Ayam setiap KK }\end{array}$ & $\begin{array}{ll}\text { 1. } & \text { Lele } 30 \text { kolam } \\
\text { 2. } & \text { Gurameh } 8 \text { kolam } \\
\text { 3. Nila dan sejenisnya } \\
22 \text { kolam }\end{array}$ & $\begin{array}{l}\text { 1. Genteng } 42 \mathrm{KK} \\
\text { 2. Anyam- } \\
\text { anyaman } 3 \mathrm{KK}\end{array}$ \\
\hline
\end{tabular}




\begin{tabular}{|c|c|c|c|c|c|}
\hline \multirow{2}{*}{ 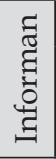 } & \multirow[b]{2}{*}{ Lokasi (Dusun) } & \multicolumn{4}{|c|}{ Sumber Daya Alam Lokal } \\
\hline & & Pertanian & Peternakan & Perikanan & $\begin{array}{l}\text { Pertambangan gol. } \\
\text { C/Industri Kecil }\end{array}$ \\
\hline 4. & $\begin{array}{l}\text { 1. Grogol } \\
\text { 2. Kadipiro }\end{array}$ & $\begin{array}{ll}\text { 1. } & \text { Padi } 30 \% \text { KK } \\
\text { 2. } & \text { Pala wija } 40 \% \text { KK } \\
\text { 3. } & \text { Tembakau } 15 \% \\
& \text { KK } \\
\end{array}$ & $\begin{array}{ll}\text { 1. } & \text { Sapi } 57 \text { ekor } \\
\text { 2. } & \text { Kerbau } 8 \text { ekor } \\
\text { 3. } & \text { Kambing } 46 \text { ekor } \\
\text { 4. } & \text { Ayam setiap KK } \\
\end{array}$ & $\begin{array}{l}\text { 1. Lele } 43 \text { kolam } \\
\text { 2. Gurameh } 11 \text { kolam } \\
\text { 3. Nila dan sejenisnya } \\
28 \text { kolam } \\
\end{array}$ & $\begin{array}{l}\text { 1. Genteng } 36 \mathrm{KK} \\
\text { 2. Anyam- } \\
\text { anyaman } 8 \mathrm{KK}\end{array}$ \\
\hline 5. & $\begin{array}{l}\text { 1. Pendekan } \\
\text { 2. Jlegongan }\end{array}$ & $\begin{array}{ll}\text { 1. } & \text { Padi } 30 \% \text { KK } \\
\text { 2. } & \text { Pala wija } 25 \% \text { KK } \\
\text { 3. } & \text { Tembakau } 50 \% \\
& \text { KK }\end{array}$ & $\begin{array}{ll}\text { 1. } & \text { Sapi } 78 \text { ekor } \\
\text { 2. } & \text { Kerbau } 6 \text { ekor } \\
\text { 3. } & \text { Kambing } 56 \text { ekor } \\
\text { 4. } & \text { Ayam setiap KK }\end{array}$ & $\begin{array}{l}\text { 1. Lele } 15 \text { kolam } \\
\text { 2. Gurameh } 6 \text { kolam } \\
\text { 3. Nila dan sejenisnya } \\
7 \text { kolam }\end{array}$ & $\begin{array}{ll}\text { 1. Tahu-tempe } 36 \\
\text { KK } \\
\text { 2. Anyam-anyaman } \\
4 \mathrm{KK}\end{array}$ \\
\hline 6. & $\begin{array}{l}\text { 1. Druju Lor } \\
\text { 2. Pete }\end{array}$ & $\begin{array}{ll}\text { 1. } & \text { Padi } 20 \% \text { KK } \\
\text { 2. } & \text { Pala wija } 40 \% \text { KK } \\
\text { 3. } & \text { Tembakau } 40 \% \\
& \text { KK } \\
\end{array}$ & $\begin{array}{ll}\text { 1. } & \text { Sapi } 66 \text { ekor } \\
\text { 2. } & \text { Kerbau } 4 \text { ekor } \\
\text { 3. } & \text { Kambing } 62 \text { ekor } \\
\text { 4. } & \text { Ayam setiap KK }\end{array}$ & $\begin{array}{l}\text { 1. Lele } 4 \text { kolam } \\
\text { 2. Nila dan sejenisnya } \\
12 \text { kolam }\end{array}$ & $\begin{array}{ll}\text { 1. Tahu-tempe } 16 \\
\text { KK } \\
\text { 2. Anyam-anyaman } \\
22 \mathrm{KK} \\
\end{array}$ \\
\hline 7. & $\begin{array}{l}\text { 1. Tegalwer } \\
\text { 2. } \text { Terwilen }\end{array}$ & $\begin{array}{ll}\text { 1. } & \text { Padi } 25 \% \text { KK } \\
\text { 2. } & \text { Pala wija } 35 \% \text { KK } \\
\text { 3. } & \text { Tembakau } 30 \% \\
& \text { KK }\end{array}$ & $\begin{array}{ll}\text { 1. } & \text { Sapi } 57 \text { ekor } \\
\text { 2. } & \text { Kambing } 45 \text { ekor } \\
\text { 3. } & \text { Ayam setiap KK }\end{array}$ & $\begin{array}{l}\text { 1. Lele } 6 \text { kolam } \\
\text { 2. Gurameh } 4 \text { kolam } \\
\text { 3. Nila dan sejenisnya } \\
14 \text { kolam }\end{array}$ & $\begin{array}{ll}\text { 1. } & \text { Tahu-tempe } 9 \\
\text { KK } \\
\text { 2. } \\
\text { Anyam- } \\
\text { anyaman } 18 \mathrm{KK}\end{array}$ \\
\hline 8. & $\begin{array}{ll}\text { 1. } & \text { Kasuran } \\
\text { Kulon } \\
\text { 2. } & \text { Druju } \\
\text { Kidul }\end{array}$ & $\begin{array}{ll}\text { 3. } & \text { Padi } 20 \% \text { KK } \\
\text { 4. } & \text { Pala wija } 40 \% \text { KK } \\
\text { 5. } & \text { Tembakau } 40 \% \\
& \text { KK }\end{array}$ & $\begin{array}{l}\text { 1. } \text { Sapi } 86 \text { ekor } \\
\text { 2. } \text { Kambing } 68 \text { ekor } \\
\text { 3. }\end{array}$ & $\begin{array}{l}\text { 1. Lele } 28 \text { kolam } \\
\text { 2. Gurameh } 16 \text { kolam } \\
\text { 3. Nila dan sejenisnya } \\
18 \text { kolam }\end{array}$ & 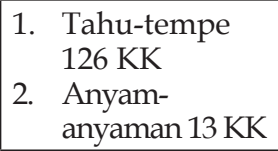 \\
\hline
\end{tabular}

\section{Kearifan Lokal}

Yang dimaksudkan Kearifan Lokal dalam penelitian adalah bahwa masyarakat desa di Kecamatan Seyegan dapat menjaga dan memelihara lingkungan, baik lingkungan abiotik seperti keberadaan air maupun lingkungan biotik, seperti pohon-pohon besar yang dianggap dapat mengeluarkan air.Kearifan Lokal ini merupakan fakta spiritual dalam sistem masyarakat desa, yang di dalamnya terdapat norma-norma sebagai makna dalam pengelolaan Sumber Daya Alam dan Lingkungan.Dibalik fakta spiritual, juga terdapat nulai-nilai sebagai makna kelestarian Sumber Daya Alam dan Lingkungan.Fakta spiritual ini menjadi spirit (semangat) dalam kehidupan sehari-hari. Norma-norma dan nilai-nilai dari fakta spiritual akan menjadikan Sumber Daya Alam dan Lingkungan dapat dimanfaatkan secara lestari.

Fakta spiritual dan ungkapan-ungkapan ini disampaikan oleh 32 informan (informan 9 sampai 40) dari budayawan lokal, seniman, tokoh adat dan tokoh agama.Data ini disusun kedalam tabel 2 dibawah ini.

Tabel 2. Norma-norma dan nilai-nilai spiritual serta ungkapan-ungkapan yang berlangsung dalam kehidupan masyarakat desa di Kecamatan Seyegan

\section{Kekuatan Spiritual}

\begin{tabular}{|c|c|c|c|c|}
\hline No & $\begin{array}{c}\text { Fakta Spiritual dalam Sistem } \\
\text { Masyarakat Desa }\end{array}$ & $\begin{array}{l}\text { Norma-norma } \\
\text { Pengelolaan SDA } \\
\text { dan Lingkungan }\end{array}$ & $\begin{array}{c}\text { Fakta Kongkrit: } \\
\text { Kegiatan anggota } \\
\text { masyarakat } \\
\text { (Fisik maupun biologis) }\end{array}$ & $\begin{array}{l}\text { Nilai kelestarian } \\
\text { SDA dan } \\
\text { Lingkungan }\end{array}$ \\
\hline 1. & $\begin{array}{l}\text { Informan } 17 \text { dan } 18 \\
\text { Mamahayu Hayuning Bawana } \\
\text { adalah bentangan jagad cilik } \\
\text { (manusia) dan jagad gede (alam } \\
\text { semesta), yang bersumber dari } \\
\text { Sangkan Paraning Dumadi. }\end{array}$ & $\begin{array}{ll}\text { - } & \text { Terpelihara } \\
\text { - } & \text { Terlindungi } \\
\text { - } & \text { Terselamatkan }\end{array}$ & $\begin{array}{l}\text { Mata air dibawah pohon } \\
\text { beringin di Tuk Sibeduk: } \\
\text { - } \quad \text { Dipugar } \\
\text { - } \quad \text { Dibersihkan } \\
\text { - } \quad \text { Pohon beringin tidak } \\
\quad \text { boleh dimusnahkan } \\
\text { - } \quad \text { Erosi tercegah } \\
\text { - } \quad \text { Udaranya sejuk }\end{array}$ & $\begin{array}{ll}\text { - } & \text { Indah } \\
\text { - } & \text { Nyaman } \\
\text { - } & \text { Selamat }\end{array}$ \\
\hline
\end{tabular}


Lanjutan Tabel 2.

\begin{tabular}{|c|c|c|c|c|}
\hline No & $\begin{array}{c}\text { Fakta Spiritual dalam Sistem } \\
\text { Masyarakat Desa }\end{array}$ & $\begin{array}{c}\text { Norma-norma } \\
\text { Pengelolaan SDA } \\
\text { dan Lingkungan }\end{array}$ & $\begin{array}{c}\text { Fakta Kongkrit: } \\
\text { Kegiatan anggota } \\
\text { masyarakat } \\
\text { (Fisik maupun biologis) }\end{array}$ & $\begin{array}{c}\text { Nilai kelestarian } \\
\text { SDA dan } \\
\text { Lingkungan }\end{array}$ \\
\hline 2. & $\begin{array}{l}\text { Informan } 19 \\
\text { Keblat papat, lima pancer, bahwa } \\
\text { manusia dan alam semesta } \\
\text { mempunyai } 4 \text { unsur yang sama } \\
\text { yaitu air, tanah, udara (angin) } \\
\text { dan api (panas, energi) Unsur } \\
\text { ke } 5 \text { adalah campuran dari ke } 4 \\
\text { unsur, sehingga: } \\
\text { - Manusia, pusatnya alam } \\
\quad \text { semesta } \\
\text { - Jiwa, pusatnya rasa dari } \\
\text { manusia }\end{array}$ & $\begin{array}{ll}\text { - } & \text { Berani dan rela } \\
\text { berkorban } \\
\text { - } \quad \text { Bersabar } \\
\text { - } \quad \text { Nrimo } \\
\text { - } \quad \text { Temen, } \\
\text { - Jangan: } \\
\text { - nggrangsang } \\
\text { - srei, drengki, } \\
\quad \text { iri, jail-methakil } \\
\text { - Angkara murka }\end{array}$ & 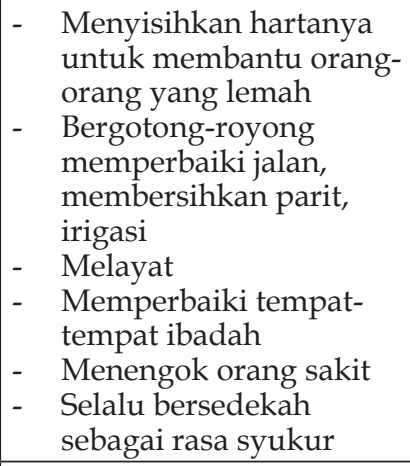 & $\begin{array}{ll}- & \text { Damai } \\
- & \text { Tenang } \\
- & \text { Tentrem }\end{array}$ \\
\hline 3. & $\begin{array}{l}\text { Informan } 20 \\
\text { Cakramanggilingan, berarti: } \\
\text { bulat dan berputar. Manusia } \\
\text { dan alam semesta dari tidak } \\
\text { ada, lalu ada, kemudian tidak } \\
\text { ada lagi. } \\
\text { Ini sifat Dununging ing Sejati. }\end{array}$ & $\begin{array}{l}\text { - Pengendalian } \\
\text { waktu } \\
\text { - } \quad \text { Kekuatan batin } \\
\text { seseorang } \\
\text { bergabung } \\
\text { dengan tujuan } \\
\text { sosial }\end{array}$ & 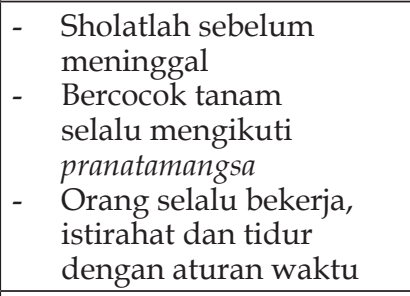 & $\begin{array}{ll}\text { - } & \text { Seimbang } \\
\text { - } & \text { Selamat } \\
\text { - } & \text { Sejahtera }\end{array}$ \\
\hline 4. & $\begin{array}{l}\text { Informan } 21 \\
\text { Manunggaling Kawula Gusti, } \\
\text { adalah perilaku yang selalu } \\
\text { eling dan prihatin, agar orang } \\
\text { mempunyai kekuatan rohani } \\
\text { yang tangguh, sehingga } \\
\text { kehidupannya punya arti dan } \\
\text { bermakna. }\end{array}$ & $\begin{array}{ll}\text { - } & \text { Rajin ibadah } \\
\text { - } & \text { Mencintai sesama } \\
\text { makhluk Tuhan }\end{array}$ & 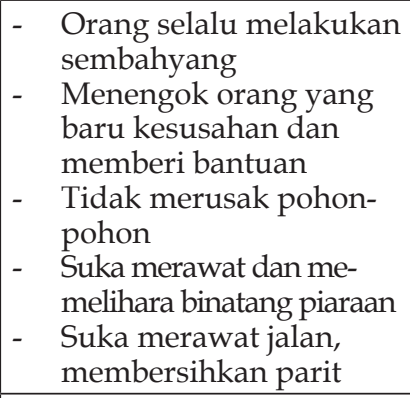 & $\begin{array}{ll}\text { - } & \text { Selamat } \\
\text { - } & \text { Damai }\end{array}$ \\
\hline 5. & $\begin{array}{l}\text { Informan } 22 \\
\text { Nrima Ing Pandum, selalu } \\
\text { menerima dengan ikhlas } \\
\text { apapun yang diberikan dari } \\
\text { Allah, dan selalu bersikap } \\
\text { pasrah dengan yang gawe urip. }\end{array}$ & $\begin{array}{ll}\text { - } & \text { Selalu bersyukur } \\
\text { - } & \text { Sabar } \\
\text { - } & \text { Santun } \\
\text { - } & \text { Tidak merusak } \\
& \text { ciptaan Allah }\end{array}$ & 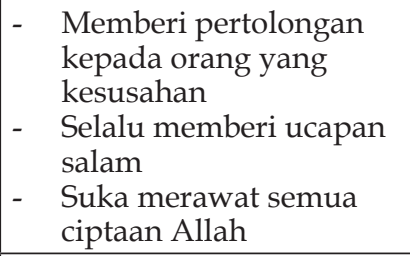 & $\begin{array}{ll}\text { - } & \text { Damai } \\
\text { - } & \text { Tenang } \\
\text { - } & \text { Bahagia } \\
\text { - } & \text { Indah }\end{array}$ \\
\hline 6. & $\begin{array}{l}\text { Informan } 22 \\
\text { Ritual Slametan seperti kenduri, } \\
\text { sajenan, kirap, merti desa dll. } \\
\text { Menyatunya manusia dengan } \\
\text { Tuhan, yang dinyatakan } \\
\text { dengan ungkapan Manung- } \\
\text { galing Kawula Gusti. Slametan } \\
\text { dulur (keblat) yang dinyatakan } \\
\text { keblat papat lima pancer. Hal ini } \\
\text { dipresentasikan oleh } 4 \text { piring } \\
\text { berisi jenang yang berwarna } \\
\text { dan identik dengan arah. } \\
\text { Jenang berwarna hitam (utara), } \\
\text { merah (selatan), kuning (barat) } \\
\text { dan putih (timur). Dari } 4 \text { warna } \\
\text { lalu dicampur menjadi warna } \\
\text { hijau, yang berpusat pada rasa } \\
\text { manusia (5 pancer). }\end{array}$ & $\begin{array}{ll}\text { - } & \text { Berdoa } \\
\text { - } & \text { Nenuwun } \\
\text { - } & \text { Pengendalian diri } \\
\text { - } & \text { Kumawula }\end{array}$ & 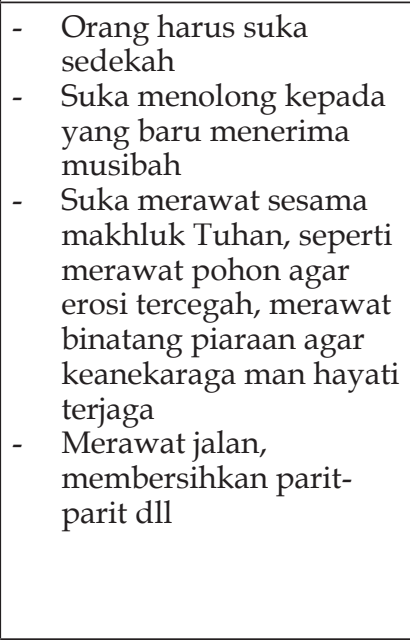 & $\begin{array}{ll}\text { - } & \text { Selamat } \\
\text { - } & \text { Damai } \\
\text { - } & \text { Harmoni } \\
\text { - } & \text { Bahagia }\end{array}$ \\
\hline
\end{tabular}




\begin{tabular}{|c|c|c|c|c|}
\hline No & $\begin{array}{c}\text { Fakta Spiritual dalam Sistem } \\
\text { Masyarakat Desa }\end{array}$ & $\begin{array}{l}\text { Norma-norma } \\
\text { Pengelolaan SDA } \\
\text { dan Lingkungan }\end{array}$ & $\begin{array}{c}\text { Fakta Kongkrit: } \\
\text { Kegiatan anggota } \\
\text { masyarakat } \\
\text { (Fisik maupun biologis) }\end{array}$ & $\begin{array}{l}\text { Nilai kelestarian } \\
\text { SDA dan } \\
\text { Lingkungan }\end{array}$ \\
\hline 7. & $\begin{array}{l}\text { Informan } 23 \\
\text { Rasa Sejati, dihadapan Allah } \\
\text { selalu menunjukkan kesucian } \\
\text { hati dan hidup selalu dengan } \\
\text { jiwa, karena ini yang abadi. } \\
\text { Bila hidup hanya mengikuti } \\
\text { nafsu, budi (pikiran) dan hal- } \\
\text { hal jasmaniah saja, ini tidak } \\
\text { abadi atau pasti hilang. Bila } \\
\text { hidup hanya diukur oleh otak } \\
\text { saja, maka akan bisa sombong, } \\
\text { grangsang, karena ini hanya } \\
\text { urusan kadonyan saja. Hiduplah } \\
\text { dengan perbuatan-perbuatan } \\
\text { yang bermoral dan hati yang } \\
\text { suci serta dengan hiasan-hiasan } \\
\text { spiritual yang selalu kumawula. }\end{array}$ & $\begin{array}{ll}\text { - } & \text { Selalu bersyukur } \\
\text { dan jujur } \\
\text { - } \\
\text { Tidak melakukan } \\
\text { kesalaha- } \\
\text { kesalahan dengan } \\
\text { sadar } \\
\text { - } \\
\text { Selalu ikhlas } \\
\text { menerima } \\
\text { cobaan-cobaan } \\
\text { hidup }\end{array}$ & $\begin{array}{l}\text { - } \quad \text { Bekerja dengan : } \\
\text { - Bercocok tanam } \\
\text { - Memelihara ikan } \\
\quad \text { dan ternak, } \\
\text { Hasilnya selalu disyukuri } \\
\text { - } \quad \text { Bila menemukan barang } \\
\quad \text { yang bukan miliknya, } \\
\text { selalu tidak ingin untuk } \\
\text { dimiliki. }\end{array}$ & $\begin{array}{ll}\text { - } & \text { Damai } \\
\text { - } & \text { Tenang } \\
\text { - } & \text { Bahagia } \\
\text { - } & \text { Indah } \\
\text { - } & \text { Selamat }\end{array}$ \\
\hline 8. & $\begin{array}{l}\text { Informan } 24 \\
\text { Nyadong Tumetesing Embun, } \\
\text { berarti hidup harus mampu } \\
\text { mensiasati riak-riak embun di } \\
\text { atas daun yang sangat indah, } \\
\text { jernih dan bersinar, sepertinya } \\
\text { meneteskan kesejahteraan yang } \\
\text { berlinang permata. Rezeki } \\
\text { memang menanti uluran nasib } \\
\text { dari Illahi, ibarat nyadong } \\
\text { tumetesing embun. Orang hanya } \\
\text { diwajibkan usaha dan berbuat, } \\
\text { sambil nenuwun. }\end{array}$ & \begin{tabular}{ll|} 
- & Orang harus \\
& selalu berdoa \\
- & Gunakan \\
& pikiran untuk \\
menemukan cara \\
menggapai tujuan \\
- & Usaha selalu \\
& terus menerus
\end{tabular} & 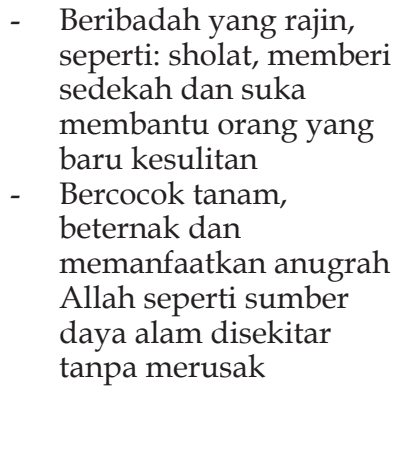 & $\begin{array}{ll}\text { - } & \text { Tenang } \\
\text { - } & \text { Damai } \\
\text { - } & \text { Sejahtera }\end{array}$ \\
\hline
\end{tabular}

\section{PEMBAHASAN}

Fakta spiritual ini ternyata mampu memberi semangat untuk memanfaatkan sumber daya alam dan lingkungan yang lestari dan harmoni yang menjadi nilai-nilai dalam kehidupan, seperti nilai rasa aman, damai, tentram, senang, indah, sejahtera dan lainlainnya. Nilai-nilai kehidupan ini terjadi, karena adanya norma-norma dalam pemanfaatan sumber daya alam dan lingkungan, seperti menjaga, melindungi, mengawetkan, tidak merusak dan sebagainya. Norma-norma ini muncul, karena adanya fakta spiritual yang tertuang dalam bentuk ungkapan-ungkapan (unen-unen), ajaran-ajaran batin (rohani) dan sebagainya, sehingga membudaya, yang selanjutnya disebut lingkungan budaya.

Spiritualitas berada pada wilayah yang sakral dengan perspektif yang lebih memberikan penekanan pada keterkaitan dari ber- bagai areal yang berbeda, yang membawa manusia secara personal memberi perubahan sosial, ilmu pengetahuan, ekonomi, dan ekologi. Spiritualitas dapat memberi penjelasan, bagaimana manusia hidup dengan sesuatu yang baik, tidak saja pada dirinya dan orang lain, tetapi juga untuk kehidupan semesta dalam planet bumi ini. Spiritualitas secara pragmatis dapat dihubungkan dalam kehidupan sehari-hari, seperti gotong-royong, kewaspadaan dan introspeksi, sikap dan perbuatan tak terpuji, membangun moral dan kepribadian, menghindari situasi yang buruk, perjuangan hidup, keadilan, pergaulan, religious, ilmu pengetahuan, dan rezeki.

Spiritualitas, memberi penekanan pada hubungan dan citra terhadap pemahaman organisme, baik manusia maupun makhluk lain sebagai titik-titik simpul dalam kerangka jaring-jaring kehidupan yang luas. Kualitas hidup yang lebih dalam akan dicapai apabila 
keterkaitan dan hubungan manusia dengan alam semakin dekat, sehingga akan lebih ditemukan penghormatan terhadap alam dan lingkungannya. Kearifan lokal lebih bersifat holistik yang menyangkut kehidupan mikrokosmos dan makrokosmos. Kearifan lokal menjadi refleksi moralitas yang didasari oleh prinsip tabu, dan hanya dipahami dalam kerangka tradisional. Dengan demikian praktek-praktek kearifan lokal di Desa Margodadi.

Masyarakat yang pola kehidupannya adalah masyarakat yang religius, spiritualis, bernorma, bernilai, dan masyarakat yang agraris merupakan masyarakat yang hidupnya sudah dianggap lengkap. Pola kehidupan dari yang satu dengan yang lain selalu berkaitan. Munculnya nilai-nilai kehidupan yang berkualitas, seperti hidup yang damai, tenang selamat, indah, tata-titi-tentrem dan sejahtera, hanya bisa dicapai karena adanya norma-norma dalam kehidupan. Norma-norma ini ada karena adanya kekuatan batin (spiritual) yang melekat dalam setiap individu. Munculnya kekuatan batin ini, karena adanya Sang Pencipta yang menjadi keyakinan dalam hati setiap individu. Manusia dan alam semesta beserta isinya ini ada, karena adanya Sang Pencipta. Manusia dan alam merupakan sesuatu yang tak terpisahkan. Manusia merupakan bagian dari alam. Dengan demikian kesejahteraan manusia berasal dari isi alam semesta. Untuk itu sumber daya alam dan lingkungan perlu dilestarikan.

Sumber daya alam yang selalu harmoni dengan lingkungannya, maka kehidupan manusia akan sejahtera. Sumber daya alam seperti lahan pertanian, pekarangan, dan lahan-lahan lain menjadi sumber kesejahteraan masyarakat ternyata seluruh warga masyarakat Kecamatan Seyegan tidak ada yang mengalami kemiskinan. Secara ratarata tingkat kesejahteraan setiap individu tidak ada yang miskin. Hal ini karena adanya hasil keseimbangan antara manusia dan alam semesta beserta isinya.

\section{SIMPULAN}

Hanya dengan kekuatan spiritual atau kekuatan batin yang tangguh sajalah, yang dapat memunculkan norma-norma dalam masyarakat yang tepat, sehingga Sumber Daya Alam dan Lingkungan dapat dimanfaatkan dengan baik tanpa harus melakukan kerusakan. Norma-norma akibat kekuatan spiritual itu dapat berwujud antara lain Sumber Daya Alam dan lingkungan dapat terpelihara, terjaga, terlindungi, terayomi, dan terselamatkan. Dengan demikian nilai-nilai sebagai makna kelestarian Sumber Daya Alam dan Lingkungan yang berwujud harmoni, indah, nyaman, bagus, selamat akan tercapai, sehingga kehidupan yang tata-titi-tentrem juga terwujud.

Pola kehidupan masyarakat Desa Margodadi adalah masyarakat yang religius, yang spiritualis, bernorma, bernilai dan berbudaya yang membentuk sebuah peradaban manusia yang berkualitas tinggi. Dengan demikian Sumber Daya Alam dan Lingkungan dapat dimanfaatkan dengan baik tanpa merusak.

Perlu diteliti juga tentang nilai-nilai keindahan, kedamaian, kenyamanan, dan sejenisnya, secara ekonomi dapat diperhitungkan. Seperti di atas, nilai kesejahteraan saja dapat diperhitungkan ekonominya. Semangat spiritual dan kearifan lokal ternyata menjadi praktek kehidupan yang etis. Untuk itu alangkah indahnya bila pemerintah dan tokoh-tokoh masyarakat dapat mewujudkan, salah satunya dalam bentuk tulisan-tulisan, seperti pada spanduk, pos ronda, tugu, gardu dan tempat-tempat lain yang bertuliskan dari ungkapan (unen-unen) peninggalan nenek moyang. Dengan demikian masyarakat dapat memahami, menghayati dan mempraktekkan dalam kehidupan sehari-hari.

\section{DAFTAR PUSTAKA}

Banair, H. 2006. Ilmu Sosial, Budaya dan Kealaman Dasar. CV Jengki Satria.

Fauzi, A. 2004.Ekonomi Sumber Daya Alam dan Lingkungan. Teori dan Aplikasi. PT. Gramedia Pustaka Utama, Jakarta.

Jalaludin, R. 2006. Rekayasa Sosial Reformasi, Revolusi, atau Manusia Besar.

Nababan, A. 1995.Kearifan Tradisional dan Pelestarian Lingkungan Hidup di 
Indonesia. Jurnal Analisis CSIS : Kebudayaan, Kearifan Tradisional, dan Pelestarian Lingkungan, Tahun XXIV No. 8 Tahun 1995.

Nasir, M. 1998. Metode Penelitian. Jakarta : Graha.

Soemirat, J. 2014. Kesehatan Lingkungan. Yogyakarta: Gadjah Mada University Press.

Supadjar, D. 2005. Wulang Wuruk Jawa. Mutiara Kearifan Lokal. Penerbit Damardjati.Yogyakarta.

Sukirno, W. 2014. Kearifan Lokal Masyarakat Desa Dalam Pengelolaan Sumber Daya
Alam Dan Lingkungan Kabupaten Sleman. Jurnal Human Media BBTKLPP Yogyakarta Volume 8, Nomor 2, Desember 2014, ISSN: 0215-5478

Sumarmi, 2014, Pengelolaan Lingkungan Berbasis Kearifan Lokal, Yogyakarta, Aditya Media, ISBN 978-602-795750-3

WWF Indonesia, 2012, Masyarakat dan Konservasi'50 Kisah yang meninspirasi dari WWF untuk Indodesia,Jakarta

Walpole, R.E. 1992. Pengantar Statistika. PT Gramedia Pustaka Utama. 